Extensional Article

\title{
The role of ubiquitin in plant-virus interactions
}

\author{
AMINALLAH TAHMASEBI ${ }^{\bowtie}$
}

Department of Agriculture, Minab Higher Education Center, University of Hormozgan, Bandar Abbas, Iran

Received: 07.05.2021

Accepted: 20.06.2021

Tahmasebi A (2021) The role of ubiquitin in plant-virus interactions. Plant Pathology Science 10(1):141-152. Doi: 10.2982/PPS.10.1.141.

\begin{abstract}
Plant viruses cause major losses to agricultural crops worldwide. Plants react to the virus infections via several defense mechanisms, such as ubiquitination. Ubiquitin (Ub) and ubiquitin proteasome system (UPS) play key role in the function modification and degradation of proteins in plants. Ub attachment to the cellular proteins alters the stability, the cellular establishment or activity of the target protein. The key role of UPS has been revealed in defense mechanisms and other plant processes. Viruses as obligate intracellular parasites have evolved mechanisms to interfere UPS. In some cases, it has been shown that viral proteins were targeted by this system. Ubiquitination plays an important role in plant-virus interaction which can lead to plant resistance or pathogenicity in the host plant. Therefore, further understanding of UPS and its role in plant-virus interaction can develop novel methods to increase resistance to viral infections in plants.
\end{abstract}

Key words: Pathogenicity, Plant pathogen, Protein, Resistance

$\triangle$ Corresponding author: Tahmasebi.info@yahoo.com 
مقاله ترويجى

\section{نقش يوبى كوئيتين در برهمكنشهاى ويروس-گياه}

$$
\begin{aligned}
& \text { امينالله طرماسبى } \\
& \text { كروه كشاورزى، مجتمع آموزش عالى ميناب، دانشعاه هرمزكان }
\end{aligned}
$$

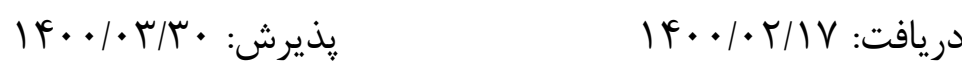

طهماسبى | (99 (1) نقش يوبى كوئيتين در برهمكنشهاى ويروس-كياه. دانش بيمارىشناسى گياهى Doi: 10.2982/PPS.10.1.141. . IFI-IOT:(1)1.

\section{جكيده}

ويروسهاى كياهى باعث خسارت عمده به محصولات كشاورزى در سراسر دنيا مىشوند. گياهان از طريق جندين سازوكار دفاعى نظير يوبى كوئيتين به آلودگىهاى ويروسى پِاسخ مىدهند. يوبى كوئيتين و سيستم يوبى كوئيتين يروتئزازوم نقش مهرى در تغيير عملكرد و تجزيه يروتئين در خياهان ايفا مى كنند. اتصال يوبى-كوئيتين به يروتئينهاى سلولى باعث تغيير در يايدارى، استقرار سلولى و يا فعاليت بروتئين هدف مىشود. نقش مهمم سيستم يوبى كوئيتين يروتئزازوم در سازو كارهاى دفاعى و ساير فرايندهاى كياه نيز مشخص شده است. ويروسها به عنوان انخلهاى اجبارى درون سلولى، سازوكارهايى را در جهت تداخل و يا استفاده از سيستم يوبى كوئيتين يروتئزوم تكامل داده اند. در مواردى هم ممكن است يروتئينهاى ويروسى توسط سيستم يوبى كوئيتين يروتئزوم مورد هدف قرار گيرند. يوبى كوئيتينه شدن يروتئينها نقش مهمى در برهمكنش گياهويروس ايفا مى كند كه مىتواند منجر به مقاومت گياه يا بيماريزايى در كَياه ميزبان شود. بنابراين، شناخت بيشتر سيستم يوبى كوئيتين :روتئازوم و بررسى نقش آن در برهمكنش ويروس-گياه، مى-تواند باعث توسعه روشهاى جديد براى افزايش مقاومت به آلودگى -

$$
\text { هاى ويروسى در زياهان شود. }
$$

وازگًان كليدى: بيماركر گياهى، بيماريزايى، يروتيين، مقاومت

\section{مقدمه}

يوبى كوئيتين :روتيين V9 آمينواسيدى است كه در بين يوكاريوتها بسيار حفاظتشده مىباشد. يوبى كوئيتينه شدن از تغييرات بعد از ترجمه مىباشد كه طى اين واكنش، واحدهاى يوبى كوئيتين به يروتيين

$\triangle$ نويسنده مسئول:Tahmasebi.info@yahoo.com 
متصل مىشوند. اين فرايند آنزيمى مىتواند زنجيرهاى از جندين واحد يوبى كوئيتين را به يروتيين هدف متصل كند. نتيجه فرايند يوبى كوئيتينه شدن شامل تجزيه يروتئزومى، فعال كردن يا تعيين جايكاه استقرار سلولى يروتيين مىباشد (Verchot 2016, Alcaide-Loridan and Jupin 2012). همجنين، اتصال يوبى كوئيتين مى تواند بهعنوان تغيير جهت (switch) مولكولى بين عملكردهاى مختلف عمل كند و يا روى توانايى : يروتيينهاى ويروسى براى برهمكنش با عاملهاى اختصاصى ميزبان اثر كذارد ( Ikeda and Dikic 2008 ). اتصال يوبى كوئيتين به يروتيينهاى سلولى در تنظيم بسيارى از مسيرهاى سيخنالدهى و همجنين در ايجاد تعادل ميان يروتيينهاى سلولى نقش مهمى ايفا مى كند ) Glickman and Ciechanover 2002 ). تجزيه تيروتئزومى وابسته به يوبى كوئيتين، سازوكار مهمى براى مهار ميزان يروتيين در سلولها مىباشد كه از طريق سيستم :روتئازوم 26S انجام مىشود. سيستم تجزيه يروتئازوم 26S از بخش تنظيمى 19S و يروتئاز $20 S$ تشكيل مىشود. يروتيينهاى غيرنرمال براى تجزيه توسط سيستم يوبى كوئيتين يروتئزازوم مورد هدف قرار مى گيرند (Sharma et al. 2016). مراحل مختلف فرايند يوبى كوئيتينه شدن توسط سه نوع آنزيم مختلف، شامل آنزيم فعال كننده يوبى كوئيتين (E1)، آنزيم متصلشونده به يوبى كوئيتين (E2) و يوبى كوئيتين ليكاز (E3) مهار مىشوند ـ در فرايند سيستم يوبى كوئيتين :يروتئزوم، در ابتدا يوبى كوئيتين توسط آنزيم فعال كننده يوبى كوئيتين وابسته به E1) ATP فعال مىشود. سيس يوبى كوئيتين فعال شده به آنزيم متصل شونده به يوبى كوئيتين (E2) از طريق انتقال كروه سيستئين متصل مىشود. آنزيم يوبى كوئيتين ليكاز E3 به عنوان جزء كليدى در تعيين اختصاصيت هدف سيستم يوبى كوئيتين يروتئازوم عمل مى كند و با يوبى كوئيتين-E2 و يروتيين هدف برهمكنش مى دهد كه منجر به تسهيل انتقال يوبى كوئيتين مىشود (Metzger et al. 2014, Yuan et al. 2013). آنزيمهاى E3 خانواده بزركى از يروتيينها را تشكيل مىدهند كه اختصاصيت يوبى كوئيتينهشدن يروتيين هدف را باعث مىشوند. اتصال يوبى كوئيتين به يروتيين هدف از طريق تشكيل ييوند ايزويِتيدى بين كليسين انتهاى كربوكسيلى خودش و آمينواسيد يذيرنده (اغلب موارد ليزين) پروتيين هدف انجام مى كيرد. سيس اين تغيير مىتواند توسط الحاق مولكولهاى يوبى كوئيتين بيشتر كسترش يابد. آمينواسيد ليزين يوبى كوئيتين به عنوان جايگاه اتصال براى اضافه شدن مولكولهاى يوبى كوئيتين بعدى مىباشد كه باعث توليد زنجيرههاى يلىيوبى كوئيتين مىشود. يوبى كوئيتين ليعاز E3 داراى جهار زيرخانواده است كه شامل HECT و U-box ،RING مىباشد (Metzger et al. 2012). از معمولترين خانوادههاى يوبى كوئيتين ليگاز E3 كه روى برهمكنشهاى گياه-بيمارگر اثر مى گذارند، مى توان به RING و اشاره كرد (Metzger et al. 2012). بسته به نوع فرايند يوبى كوئيتينهشدن (منفرد يا جندكانه)، طول زنجيره (كمتر يا بيشتر از f مولكول يوبى كوئيتين) و نحوه انشعاب زنجيره، 
يوبى كوئيتينهشدن بروتيينها عملكردهاى مختلفى در سلول ايفا مى كنند. يوبى كوئيتينهشدن منفرد مى تواند به عنوان يك پيام براى ترميم DNA و انتقال مواد توسط وزيكل عمل كند، در حالى كه يوبى كوئيتينهشدن קندكانه مىتواند به عنوان نشانكرهايى براى فعاليت يروتيين كيناز مورد استفاده قرار

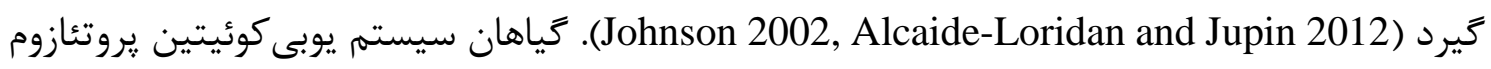
را به عنوان فرايند تنظيمى مهمى در رشد، يُيرى، سيخنال دهى هورمون، ايمنى، تنظيم ساختار

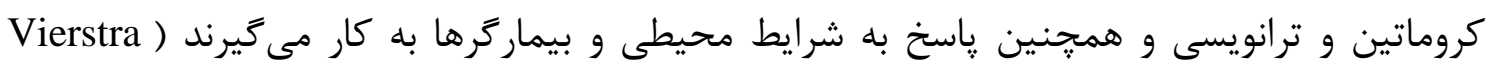

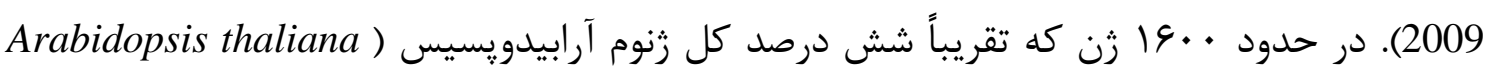

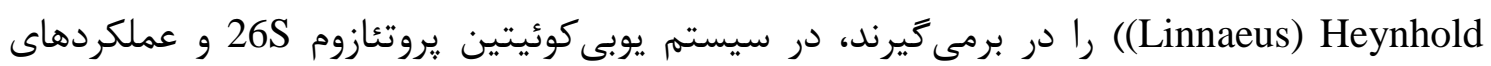
مرتبط با آن دخيل هستند (Vierstra 2009, Mazzucotelli et al. 2006). همجنين مشخص شده

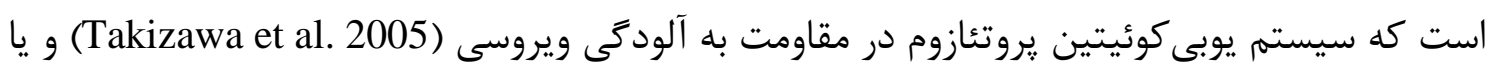

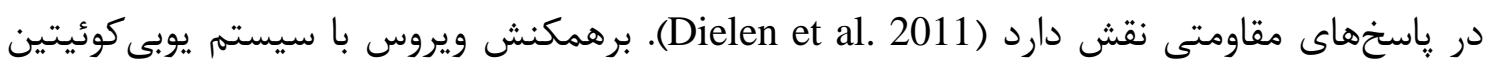

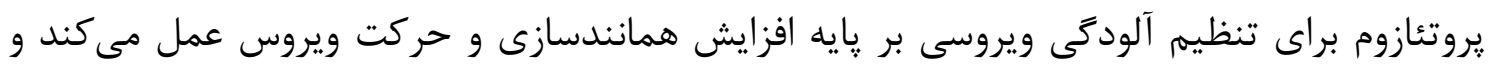
ميزان تجمع RNA را براى برقرارى يك برهمكنش زيوايرور (Biotrophic) موفق تنظيم مى كند. از

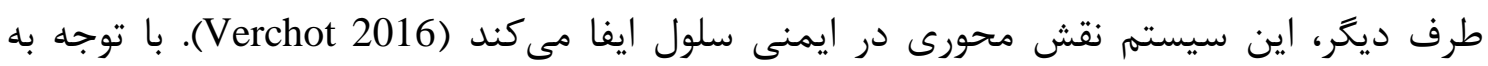

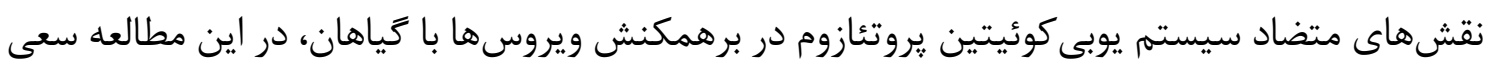

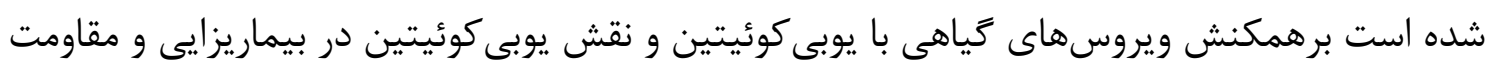
به ويروس ها بيان شود.

\section{به كاركيرى سيستم يوبى كوئيتين بروتثازوم توسط ويروسهاى كياهى}

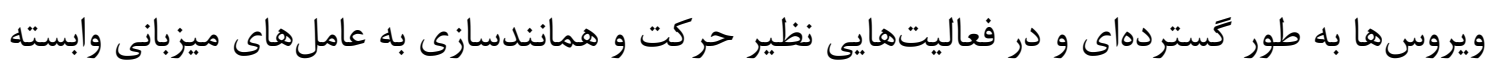

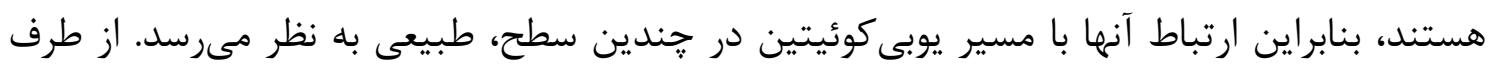
ديخر، گياهان به آلودكى ويروسى از طريق جندين سازوكار نظير يوبى كوئيتينهشدن ياسخ مىدهند

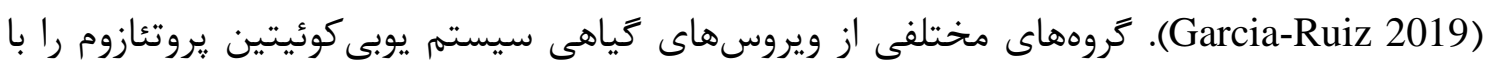
جندين سازوكار مختلف به نفع خود به كار مى گيرند. ويروسهاى كياهى توانايى القاء، بازدارندكى و تغيير اختصاصيت آنزيمهاى ميزبانى مرتبط با يوبى كوئيتين بهخصوص آنزيمهاى ليعاز E3 را دارند. همجنين ويروسهاى كياهى ممكن است آنزيمهاى هيدرولاز يوبى كوئيتين را كد كنند. اين سازوكارها مى توانند با ايجاد محيط سلولى مناسب و يا بازدارندگى سازوكارهاى دفاعى ميزبان به نفع ويروس عمل كنند (Alcaide-Loridan and Jupin 2012). تعدادى از بروتيينهاى مرتبط با سيستم يوبى كوئيتين

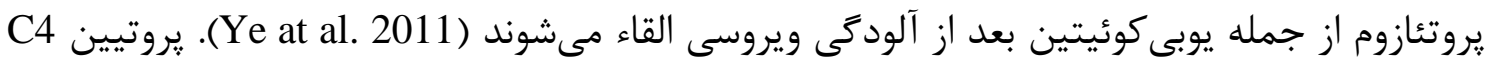


ويروس بِيجيدَى شديد بوته جغندرقند (Beet severe curly top virus, BSCTV) باعث افزايش بيان آنزيم ليعاز E3 از نوع RING مىشود (Lai et al. 2009). اين آنزيم تنظيم جرخه سلولى را از طريق

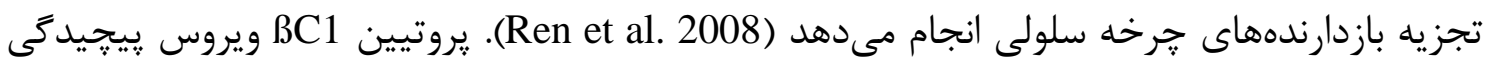

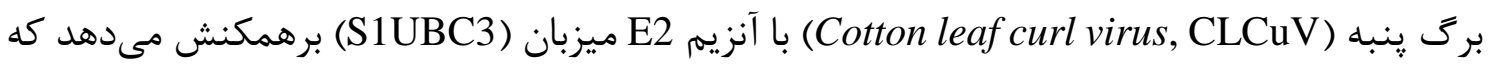
به منظور تغيير سيستم يوبى كوئيتين تروتئزوم ميزبان مىباشد (Eini et al. 2009, Chen et al. 2013).

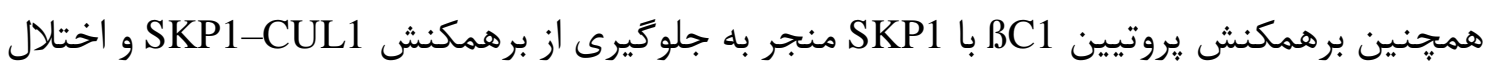

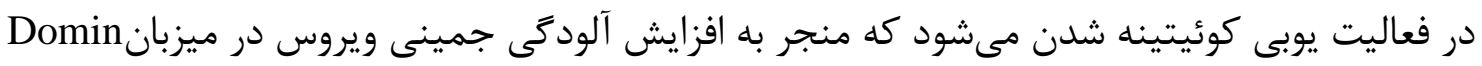
Nicotiana benthamiana به كاهش ميزان يروتيينهاى يلى يوبى كوئيتينه شد كه اين امر به دليل بازدارندكى مرحله اتصال به يوبى برى بران كوئيتين مىباشد. همجنين اين برهمكنش و اختلال در سيستم با افزايش شدت نشانه در كياهان مرتبط مىباشد و ممكن است باعث اختلال در مسيرهاى سيخنالدهى هورمونى و نمو گياه شود كه توسط

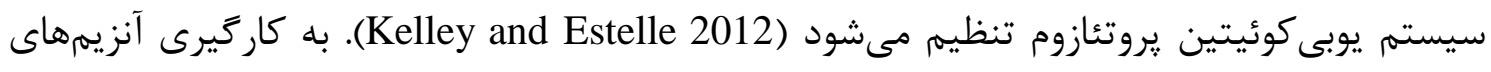
ليكاز E3 ميزبان روش معمولى است كه ويروس هاى كياهى از آن استفاده مى كنند. در همه موارد كزارش

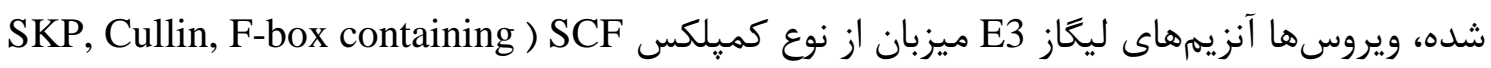
complex

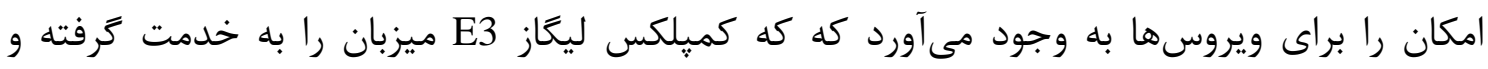

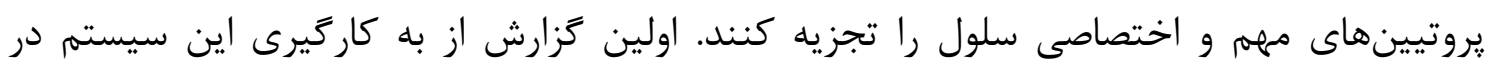
نانوويروس زردى بافت مرده باقلا (Faba bean necrotic yellows virus, FBNYV) بود. يروتيين

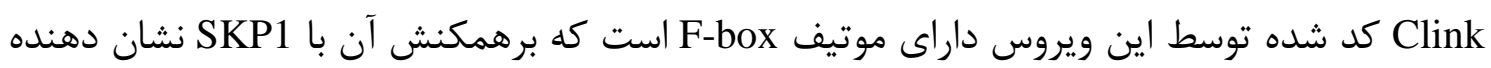

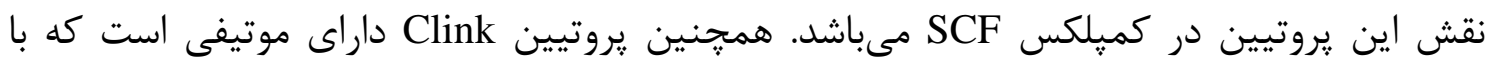

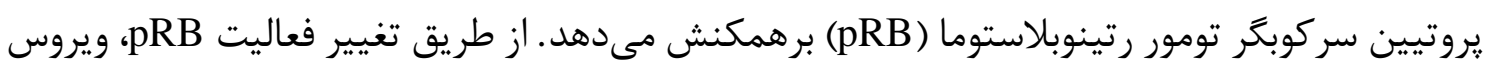
اين ظرفيت را دارد كه هرخه سلولى را تغيير دهد و يك محيط سلولى مناسب براى همانندسازى كاراى

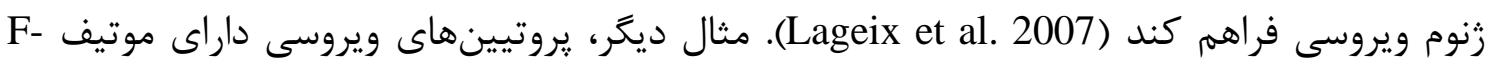

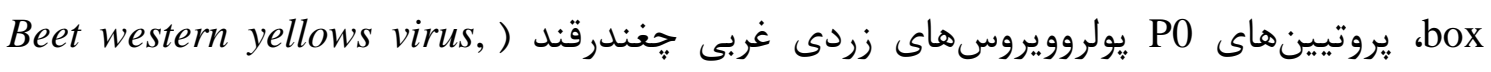

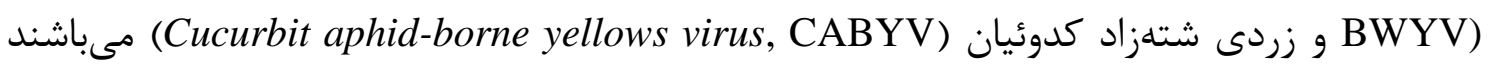
(Suppressors of RNA silencing) كه سركوبكرهاى خاموشى آراناى (Pazhouhandeh et al. 2006)

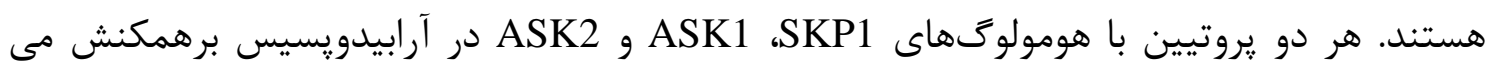

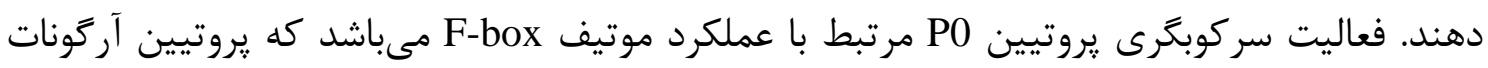


را در مسير خاموشى آراناى مورد هدف قرار مىدهد (Baumberger et al. 2007) (AGO1) P7-2 در ويروس كوتولكى ركه سياه برنج (Rice black-streaked dwarf virus, SRBSDV)، بروتيين F-box يروتئازوم را به كار مى گيرد. بر خلاف يروتيينهاى F-box يولرو ويروسى، يروتيين P7-2 سركوبكر خاموشى رن نمىباشد و آرگونات را هم براى تجزيه مورد هدف قرار نمىدهد. اين احتمال مىرود كه يروتيين P7-2 ساير سوبستراهاى سلولى را مورد هدف قرار دهد و يا اينكه با اختلال در كميلكس يوبى كوئيتين يروتئازوم، باعث سركوب دفاع و ايمنى گياه در برابر ويروس شود (Wang et al. 2013). در Beet necrotic yellow vein و سازوكار ديكر، يروتيين P25 ويروس رگبرى زردى نكروتيك جغندرقند

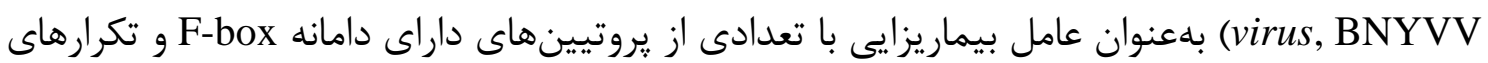
kelch Pمكن است از برهمكنش بين F-box و ASK1 SKP1، ملو Fيرى كند و باعث اختلال در تجزيه سوبستراى F-box در جغندرقند توسط سيستم يوبى كوئيتين :روتئازوم شود و در نتيجه تشخيص درست هدف را تغيير و منجر به گسترش نشانه ويروس شود (Thiel et al. 2012).

\section{جلوگيرى از تجزيه يروتيينهاى ميزبانى و ويروسى} برهمكنش يروتيين 2b ويروس موزائيك خيار (Cucumber mosaic virus, CMV) با يروتيينهاى سركوبخر JAZ باعث حفاظت اين يروتيينها از مسير تجزيه يوبى كوئيتين يروتئازوم 26S و منجر به سركوب سيخنال دهى جاسمونات در كياهان آلوده به ويروس آرابيدويسيس مىشود (Wu et al. 2017). يزوهشها نشان داده است كه سركوبكر خاموشى HC-Pro در يوتىويروسهايى نظير ويروس موزائيك كاهو (Lettuce mosaic virus, LMV)، ويروس Y سيب زمينى (Potato Virus Y, PVY) و ويروس لكه حلقوى يإيا (Papaya ring spot virus, PRSV) با زيرواحدهاى مختلفى از يروتئازوم20S برهمكنش مى دهد كه اين برهمكنش ممكن است در تنظيم فعاليت يروتئزازوم و دفاع گياه عليه ويروس نقش مهمى را ايفا كند (Sorel et al. 2018). يروتيين سركوبخر خاموشى C2 ويروس بيجِيدگى شديد بوته جغندرقند با آدنوزيل-متيونين دكربوكسيلاز (SAMDC1) برهمكنش كرده و بدين طريق از تجزيه يروتئازومى SAMDC1 جلو گيرى مى كند. اين فرايند روى متيله شدن دىاناى ويروسى و ميزبان اثر مى كذارد و از طريق مهار سازوكار دفاع ضد ويروسى خاموشى زن در زياهان، تكثير ويروس را تسهيل

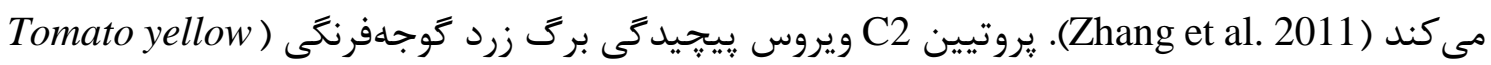
(leaf curl virus, TYLCV تواند سيستم يوبى كوئيتين يروتئزازوم را با مورد هدف قرار دادن تعداد زيادى از ليعازهاى E3 به خدمت 
كرفته و باعث اختلال در فعاليت كميلكس SCF شود و روى وضعيت روبيلهشدن آنها اثر كذارد (2011 ع Lozano-Duran et al. كوئيتين مىباشد، درحاليكه جدا شدنشان توسط فعاليت دىروبيلهشدن كميلكس سيخنالوزوم COP9

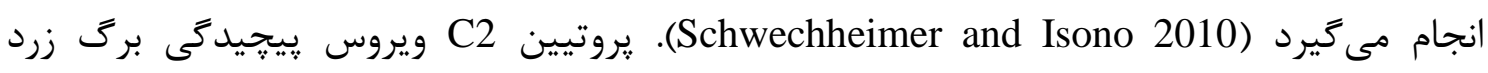
كوجهفرنكى و ويروس يِيجيدگى بوته جغندرقند باCSN5 (بخش كاتاليزور سيگنالوزوم COP9) برهمكنش مى دهد و باعث اختلال در فعاليت CSN5 و جلوكيرى از حذف واحدهاى شبه يوبى كوئيتين از كولين مىشود كه منجر به بازدارندكى در ييام رسانى دفاع جاسمونات مىشود ( Lozano-Duran et

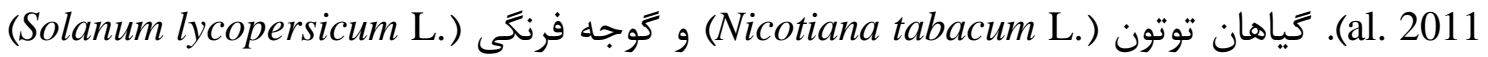
آنزيم ليعاز E3، RFP1 را كد مى كنند كه همراه با آنزيم Eb3، Eb3 منجر به يوبى كوئيتينه شدن و تجزيه يروتيين BC1 ويروسى توسط سيستم يوبى كوئيتين : يروتئزوم 26S و كاهش نشانه ويروسى مىشود

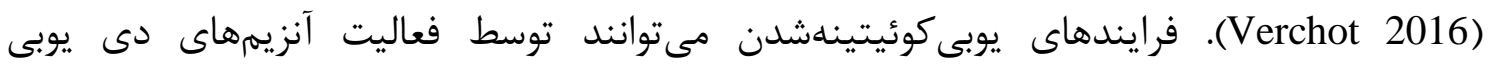
كوئيتينه كننده بركشتيذير باشند. هنين فعاليتى در مورد ويروس موزائيك زرد شلغم (Turnip yellow كزارش شده است (mosaic virus, TYMV كوئيتينهكننده اين ويروس توسط دامانه سيستئين : يروتييناز : يروتيين همانندسازى مىباشد كه در فراورى يروتئوليتيك داخلى يروتيينهاى ويروسى لازم مىباشد. اين آنزيم بلطور اختصاصى يليمراز

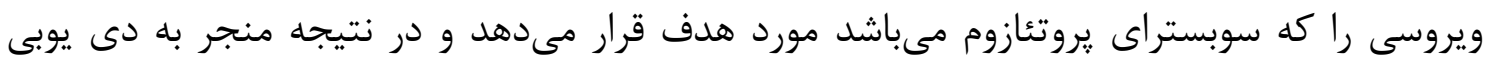
كوئيتينهشدن و پايدارى اين يروتيين مىشود (Camborde et al. 2010). بسيارى از ويروس هاى كياهى دامانهاى سيستئين يروتييناز را كد مى كنند كه در صورت مشخص شدن فعاليت آنزيمى دى يوبى كوئيتينهگى آنها، مىتوان عملكرد مهرى براى جنين فعاليتهايى در اين ويروسها ييشنهاد كرد (Martelli et al. 2007). يروتيين شبه يوبى كوئيتين SUMO مىتواند به آمينواسيدهاى ليزين يروتيينهاى هدف مشابه سازوكار يوبى كوئيتين متصل شود. عملكردهاى اتصال SUMO بر اساس يروتيين هدف متفاوت مىباشند. از نتايج عمده اين سازوكار بازدارندگى، تغيير يا توانايى انجام

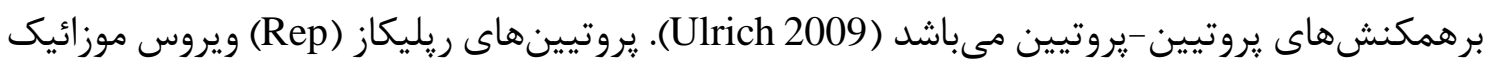
طلايى گوجهفرنكى (Tomato golden mosaic virus, TGMV)، ويروس موزائيك آفريقايى كاساوا

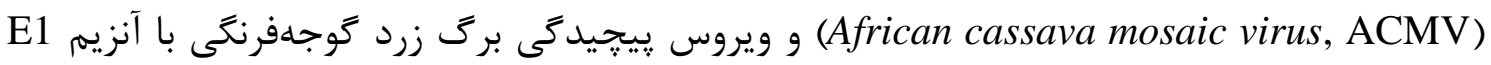
ميزبان برهمكنش مىدهند. برهمكنش بين يروتيين Rep و آنزيم SUMO E1 براى SUMO همانندسازى دىاناى و آلودگى ويروسى لازم مىباشند (Sanchez-Duran et al. 2011). همجنين 
سومويله شدن (Sumoylation) يروتيين NIb براى آلودكى ويروس موزائيك شلغم ( Turnip mosaic ضرورى است (Xirus, TuMV) (Xiong and Wang 2013).

\section{يوبى كوئيتينه شدن يروتيينهاى ويروسى}

ويروس كوتولنى بوته انبوهى در گوجه فرنكى (Tomato bushy stunt virus, TBSV)، آنزيم E2 بلهعنوان جزء جديدى از كميلكس همانندسازى ويروس مىباشد و براى فعاليت كاراى ريليكاز ضرورى مىباشد. Cdc34p بهطور مستقيم با يروتيين همانندسازى p33 ويروس كوتولكى بوته انبوهى گوجه فرنكى برهمكنش مىدهد و منجر به يوبى كوئيتينه شدن منفرد يا دو كانه مىشود. يوبى كوئيتينه

شدdosomal sorting complexes required ) ESCRT باعث برهمكنش با : يروتيينهاى p33 مىشود و آنها را در جايعاههاى همانندسازى ويروس قرار مىدهد كه براى فعاليت (for transport مناسب ريليكاز و حفاظت از آراناى ويروسى لازم مىباشد (Barajas et al. 2009). در بعضى موارد زيرواحدهاى يروتئزومى E3 و يا آنزيمهاى دى يوبى كوئيتينهكننده سلولى روى كارايى همانندسازى ويروس اثر مى گذارند كه به طور مستقيم به تجزيه يروتيينهاى ويروسى مربوط نمىشود. اين تأثير ممكن است بخاطر اثرات غيرمستقيم باشد كه توسط تنش سلولى و يا اختلال در تعادل يوبى كوئيتين ايجاد مىشود (Gancarz et al. 2011). بنابراين يوبى كوئيتينه شدن :روتيين p33 براى همانندسازى ويروس مهرم مىباشد. يوبى كوئيتين نقش مهممى در آلودكى تومبوسويروس ايفا مى كند. Rpn11p از اجزى كليدى يروتئازوم 26S توسط ويروس كوتولنى بوته انبوهى گوجه فرنگى به كار گرفته مىشود كه احتمالاً براى شركت در سركوب نوتركيبى RNA در جايعاههاى همانندسازى ويروس نقش داشته باشد (Verchot 2016). يليمراز \&\& كيلودالتونى ويروس موزائيك زرد شلغم توسط سيستم يوبى كوئيتين يروتئزوم در اواخر زمان آلودگى تجزيه مىشود كه باعث كاهش همانندسازى ويروس و تنظيم فرايندهاى همانندسازى مىشود (Camborde et al. 2010). فرايندهاى تجزيه و يوبى كوئيتينه كنندگى مى توانند توسط يروتيين تكثيرى ديخر ويروس موزائيك زرد شلغم با فعاليت آنزيم دى يوبى كوئيتينهكنندهى ممانعت شوند. تعدادى از يروتيينهاى حركتى ويروسها فقط در طى اوايل تا اواسط آلودگى ويروسى تجمع مى يابند و بهنظر مىرسد كه زمان بيان براى آلودىى ويروس ضرورى باشد. تجزيه يروتيين حركتى ويروس موزائيك توتون (Tobacco mosaic virus, TMV)، ويروس موزائيك زرد شلغم، ويروس برى قاشقى سيبزمينى (Potato leafroll virus, PLRV) و همجنين ثروتيين TGBp3 ويروس ايكس سيب زمينى (Potato virus X, PVX et al. ) توسط سيستم يوبى كوئيتين يروتئازوم گزارش شده است 2008). همجنين يوبى كوئيتين ليعاز E3، يروتيين ريليكاز ويروس موزائيك بامبو ( Bamboo mosaic

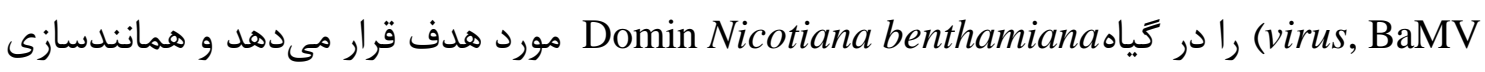


ويروس را محدود مى كند. خاموش كردن زن يوبى كوئيتين ليخاز E3 منجر به افزايش همانندسازى ويروس شد (Chen et al. 2019). يروتيين يوششى و حركتى ويروس موزائيك توتون تشكيل تجمعاتى در داخل سلول كياهى مىدهند كه توسط سيستم يوبى كوئيتين يروتئزازوم مورد هدف قرار مى كيرند و از سلول در برابر سميت سلولى ناشى از تجمعات بالاى اين يروتيينها محافظت مى كند ( Jockusch

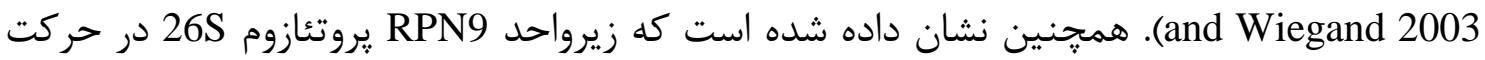
Reichel and Beachy ) سيستميك ويروس موزائيك توتون و ويروس موزائيك شلغم مشاركت دارد 2000). يروتيين شبه يوبى كوئيتين له با سركوبكر خاموشى pice stripe virus, ( ويروس نوارى برنج

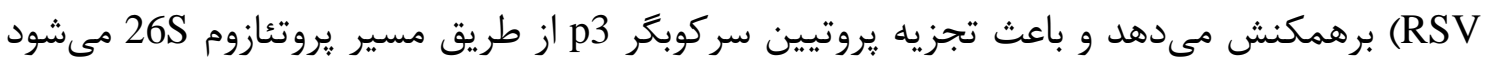

\section{نتيجه}

سيستم يوبى كوئيتين از اجزاى مهم و كليدى دفاع كياه عليه بيماركرها به شمار مىرود كه مىتواند در

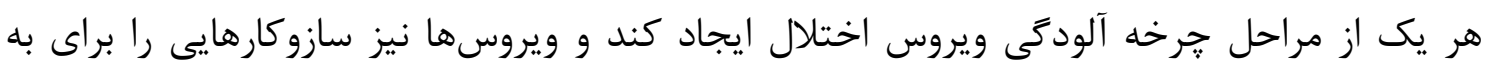
كار كيرى يا اختلال در اين سيستم به وجود آوردهاند. علاوه بر فعاليتهاى تجزيه يروتيين، سيستم يوبى كوئيتين يروتئزوم ممكن است از طريق فعاليتRNase بخش 20 در مسير دفاعى عليه ويروسها عمل كند. اين سيستم نه تنها در دفاع گياهان استفاده مىشود، بلكه به عنوان هدفى براى بعضى از بيماركرها مىباشد كه سازوكارهايى را براى جلوكيرى و يا استفاده از اين سيسته تكامل دادهاند. به كاركيرى يروتيينهاى هدف ميزبان توسط ويروسها با استفاده از اين سيستم مىتواند باعث مساعد شدن محيط سلولى و يا سركوب سازوكارهاى دفاعى شود. شناسايى نقشهاى جديد سيسته يوبى كوئيتين يروتئزازوم در برهمكنشهاى ويروس-كياه مىتواند منجر به شناسايى سازوكارهاى جديد و

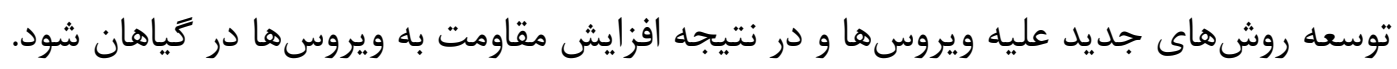

\section{References}

Alcaide-Loridan C, Jupin I (2012) Ubiquitin and plant viruses, let's play together. Plant Physiology 160:72-82.

Barajas D, Jiang Y, Nagy PD (2009) A unique role for the host ESCRT proteins in replication of Tomato bushy stunt virus. PLoS Pathogens 5:e1000705.

Baumberger N, Tsai CH, Lie M, Havecker E, Baulcombe DC (2007) The Polerovirus silencing suppressor P0 targets argonaute proteins for degradation. Current Biology 17:1609-1614.

Camborde L, Planchais S, Tournier V, Jakubiec A, Drugeon G, Lacassagne E, Pflieger S, Chenon M, Jupin I (2010) The ubiquitin-proteasome system regulates the 
accumulation of Turnip yellow mosaic virus RNA-dependent RNA polymerase during viral infection. The Plant Cell 22:3142-3152.

Chen B, Lin L, Lu Y, Peng J, Zheng H, Yang Q, Rao S, Wu G, Li J, Chen Z, Song B (2020) Ubiquitin-Like protein 5 interacts with the silencing suppressor $\mathrm{p} 3$ of rice stripe virus and mediates its degradation through the $26 \mathrm{~S}$ proteasome pathway. PLoS Pathogens 16:e1008780.

Chen IH, Chang JE, Wu CY, Huang YP, Hsu YH, Tsai CH (2019) An E3 ubiquitin ligase from Nicotiana benthamiana targets the replicase of Bamboo mosaic virus and restricts its replication. Molecular Plant Pathology 20:673-684.

Chen L, Cheng C, Zhang C, Yao Q, Zhao E (2013) Ubiquitin-conjugating enzyme involved in the immune response caused by pathogens invasion. Open Journal of Immunology 3:93-97.

Chenon M, Camborde L, Cheminant S, Jupin I (2012) A viral deubiquitylating enzyme targets viral RNA-dependent RNA polymerase and affects viral infectivity. The EMBO Journal 31:741-753.

Dielen AS, Sassaki FT, Walter J, Michon T, Menard G, Pagny G, Krause-Sakate R, Maia IDG, Badaoui S, Le Gall O, Candresse T (2011) The 20S proteasome alpha(5) subunit of Arabidopsis thaliana carries an RNase activity and interacts in planta with the lettuce mosaic potyvirus HcPro protein. Molecular Plant Pathology 12:137-150.

Eini O, Dogra S, Selth LA, Dry IB, Randles JW, Rezaian MA (2009) Interaction with a host ubiquitin-conjugating enzyme is required for the pathogenicity of a geminiviral DNA beta satellite. Molecular Plant-Microbe Interactions 22:737-746.

Gancarz BL, Hao L, He Q, Newton MA, Ahlquist P (2011) Systematic identification of novel, essential host genes affecting bromovirus RNA replication. PLoS One 6:e23988.

Garcia-Ruiz H (2019) Host factors against plant viruses. Molecular Plant Pathology 20:1588-1601.

Glickman MH, Ciechanover A (2002) The ubiquitin-proteasome proteolytic pathway: destruction for the sake of construction. Physiological Reviews 82:373-428.

Ikeda F, Dikic I (2008) A typical ubiquitin chains: new molecular signals. Protein Modifications: Beyond the Usual Suspects' review series. EMBO Reports 9:536-542.

Jia Q, Liu N, Xie K, Dai Y, Han S, Zhao X, Qian L, Wang Y, Zhao J, Gorovits R, Xie D (2016) CLCuMuB $\beta \mathrm{C} 1$ subverts ubiquitination by interacting with NbSKP1s to enhance geminivirus infection in Nicotiana benthamiana. PLoS Pathogens 12(6): 1005668 .

Jockusch H, Wiegand C (2003) Misfolded plant virus proteins: Elicitors and targets of ubiquitylation. FEBS Letters 545:229-232.

Johnson ES (2002) Ubiquitin branches out. Nature Cell Biology 4:295-298.

Ju HJ, Ye CM, Verchot-Lubicz J (2008) Mutational analysis of PVX TGBp3 links subcellular accumulation and protein turnover. Virology 375:103-117.

Kelley DR, Estelle M (2012) Ubiquitin-mediated control of plant hormone signaling. Plant Physiology 160:47-55. 
Lageix S, Catrice O, Deragon JM, Gronenborn B, Pélissier T, Ramírez BC (2007) The nanovirus-encoded Clink protein affects plant cell cycle regulation through interaction with the retinoblastoma-related protein. Journal of Virology 81:4177-4185.

Lai J, Chen H, Teng K, Zhao Q, Zhang Z, Li Y, Liang L, Xia R, Wu Y, Guo H, Xie Q (2009) RKP, a RING finger E3 ligase induced by BSCTV C4 protein, affects geminivirus infection by regulation of the plant cell cycle. The Plant Journal 57:905917.

Lechner E, Achard P, Vansiri A, Potuschak T, Genschik P (2006) F-box proteins everywhere. Current Opinion in Plant Biology 9:631-638.

Lozano-Durán R, Rosas-Díaz T, Gusmaroli G, Luna AP, Taconnat L, Deng XW, Bejarano ER (2011) Geminiviruses subvert ubiquitination by altering CSN-mediated derubylation of SCF E3 ligase complexes and inhibit jasmonate signaling in Arabidopsis thaliana. The Plant Cell 23:1014-1032.

Martelli GP, Adams MJ, Kreuze JF, Dolja VV (2007) Family Flexiviridae: a case study in virion and genome plasticity. Annual Review of Phytopathology 45:73-100.

Mazzucotelli E, Belloni S, Marone D, De Leonardis AM, Guerra D, Di Fonzo N, Cattivelli L, Mastrangelo AM (2006) The E3 ubiquitin ligase gene family in plants: regulation by degradation. Current Genomics 7:509-522.

Metzger MB, Hristova VA, Weissman AM (2012) HECT and ring finger families of e3 ubiquitin ligases at a glance. Journal of Cell Science 125:531-537.

Metzger MB, Pruneda JN, Klevit RE, Weissman AM (2014) RING-type E3 ligases: master manipulators of E2 ubiquitin-conjugating enzymes and ubiquitination. Biochimica et Biophysica Acta (BBA)-Molecular Cell Research 1843:47-60.

Pazhouhandeh M, Dieterle M, Marrocco K, Lechner E, Berry B, Brault V, Hemmer O, Kretsch, T, Richards KE, Genschik P, Ziegler-Graff V (2006) F-box-like domain in the polerovirus protein $\mathrm{P} 0$ is required for silencing suppressor function. Proceedings of the National Academy of Sciences of the United States of America 103:1994-1999.

Reichel C, Beachy RN (2000) Degradation of Tobacco mosaic virus movement protein by the 26s proteasome. Journal of Virology 74:3330-3337.

Ren H, Santner A, del Pozo JC, Murray JA, Estelle M (2008) Degradation of the cyclindependent kinase inhibitor KRP1 is regulated by two different ubiquitin E3 ligases. The Plant Journal 53:705-716.

Sanchez-Durán MA, Dallas MB, Ascencio-Ibañez JT, Reyes MI, Arroyo-Mateos M, Ruiz-Albert J, Hanley-Bowdoin L, Bejarano ER (2011) Interaction between geminivirus replication protein and the SUMO-conjugating enzyme is required for viral infection. Journal of Virology 85:9789-9800.

Schwechheimer C, Isono E (2010) The COP9 signalosome and its role in plant development. European Journal of Cell Biology 89:157-162.

Sharma B, Joshi D, Yadav PK, Gupta AK, Bhatt TK (2016) Role of ubiquitin-mediated degradation system in plant biology. Frontiers in Plant Science 7:806.

Sorel M, Mooney B, de Marchi R, Graciet E (2018) Ubiquitin/Proteasome system in plant pathogen responses. Annual Plant Reviews Online 15:65-116. 
Takizawa M, Goto A, Watanabe Y (2005) The tobacco ubiquitin-activating enzymes $\mathrm{NtE} 1 \mathrm{~A}$ and $\mathrm{NtE} 1 \mathrm{~B}$ are induced by Tobacco mosaic virus, wounding and stress hormones. Molecules \& Cells 19:228-231.

Thiel H, Hleibieh K, Gilmer D, Varrelmann M (2012) The P25 pathogenicity factor of BNYVV targets the sugar beet $26 \mathrm{~S}$ proteasome involved in the induction of a hypersensitive resistance response via interaction with an F-box protein. Molecular Plant-Microbe Interactions 25:1058-1072.

Ulrich HD (2009) The SUMO system: an overview. Methods in Molecular Biology 497:3-16.

Verchot J (2016) Plant virus infection and the ubiquitin proteasome machinery: arms race along the endoplasmic reticulum. Viruses 8:314.

Vierstra RD (2009) The ubiquitin-26S proteasome system at the nexus of plant biology. Nature Reviews Molecular Cell Biology 10:385-397.

Wang Q, Tao T, Han Y, Chen X, Fan Z, Li D, Yu J, Han C (2013) Nonstructural protein p7-2 encoded by Rice black-streaked dwarf virus interacts with skp1, a core subunit of scf ubiquitin ligase. Virology Journal 10:1-12.

Wu D, Qi T, Li WX, Tian H, Gao H, Wang J, Ge J, Yao R, Ren C, Wang XB, Liu Y (2017) Viral effector protein manipulates host hormone signaling to attract insect vectors. Cell Research 27:402-415.

Xiong R, Wang A (2013) SCE1, the SUMO-conjugating enzyme in plants that interacts with NIb, the RNA-dependent RNA polymerase of Turnip mosaic virus, is required for viral infection. Journal of Virology 87:4704-4715.

Ye C, Dickman MB, Whitham SA, Payton M, Verchot J (2011) The unfolded protein response is triggered by a plant viral movement protein. Plant Physiology 156:741755.

Yuan X, Zhang S, Liu S, Yu M, Su H, Shu H, Li X (2013) Global analysis of ankyrin repeat domain C3HC4-type RING finger gene family in plants. PLoS One 8:e58003.

Zhang Z, Chen H, Huang X, Xia R, Zhao Q, Lai J, Teng K, Li Y, Liang L, Du Q, Zhou X, Guo H, Xie Q (2011) BSCTV C2 attenuates the degradation of SAMDC1 to suppress DNA methylation-mediated gene silencing in Arabidopsis. The Plant Cell 23:273-288. 